\title{
Improving Public Infrastructure in the Philippines
}




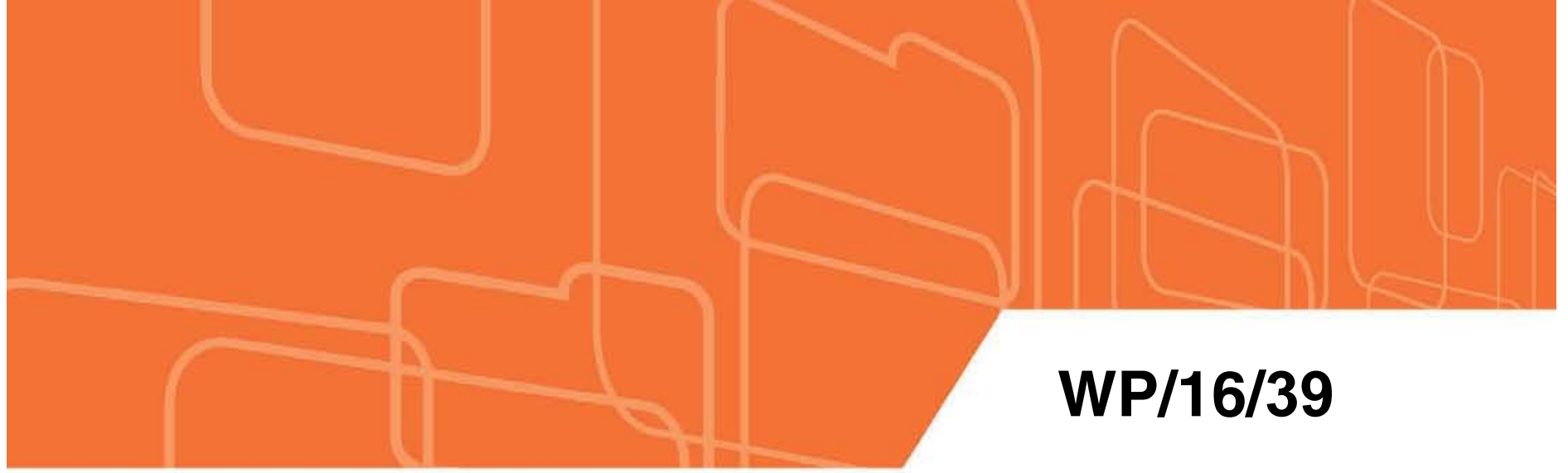

\section{IMF Working Paper}

Improving Public Infrastructure in the Philippines

by Takuji Komatsuzaki

I N T E R N A T I O N A L M O N E T A R Y FU N D 


\title{
IMF Working Paper
}

Asia Pacific Department

\section{Improving Public Infrastructure in the Philippines Prepared by Takuji Komatsuzaki ${ }^{1}$}

\author{
Authorized for distribution by Chikahisa Sumi
}

February 2016

\section{IMF Working Papers describe research in progress by the author(s) and are published to elicit comments and to encourage debate. The views expressed in IMF Working Papers are those of the author(s) and do not necessarily represent the views of the IMF, its Executive Board, or IMF management.}

\begin{abstract}
This paper explores the macroeconomic effects of improving public infrastructure in the Philippines. After benchmarking the Philippines relative to its neighbors in terms of level of public capital and quality of public infrastructure, and public investment efficiency, it uses model simulations to assess the macroeconomic implications of raising public investment and improving public investment efficiency. The main results are as follows: (i) increasing public infrastructure investment results in sustained gains in output; (ii) the effects of improving public investment efficiency are substantial; and (iii) deficit-financed increases in public investment lead to higher borrowing costs that constrain output increases over time, underscoring the importance of revenue mobilization.
\end{abstract}

JEL Classification Numbers: E22, E62, H54

Keywords: Infrastructure, Public Investment Efficiency, Philippines

Author's E-Mail Address: tkomatsuzaki@,imf.org

\footnotetext{
${ }^{1}$ The author would like to thank the Philippines authorities, Chikahisa Sumi, Ha Vu, Prakash Loungani, Grace Li, IMF's Philippines team, and seminar participants at the Central Bank of the Philippines and the International Monetary Fund for insightful comments.
} 
Contents

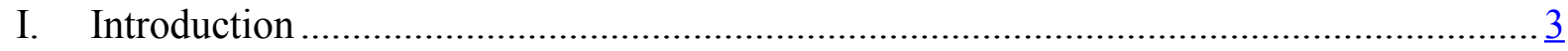

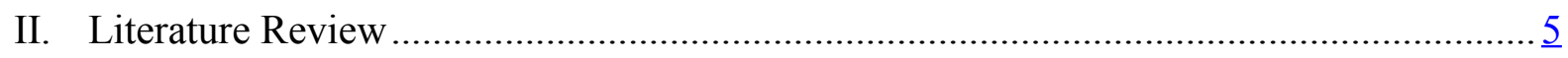

III. The State of Public Infrastructure in the Philippines ............................................... $\underline{5}$

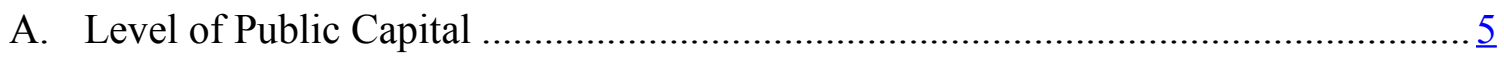

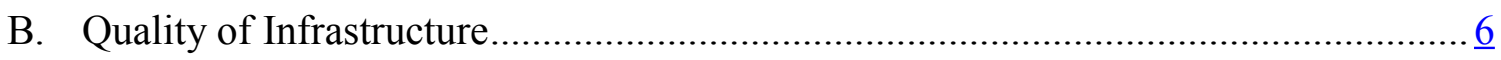

C. Public Investment Efficiency ..................................................................

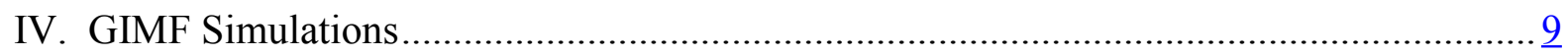

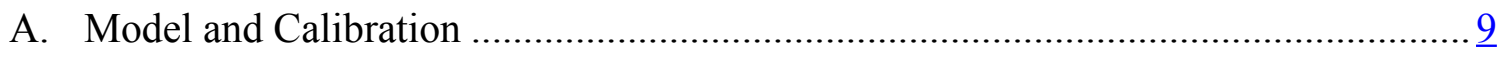

B. Baseline Results ........................................................................................ 11

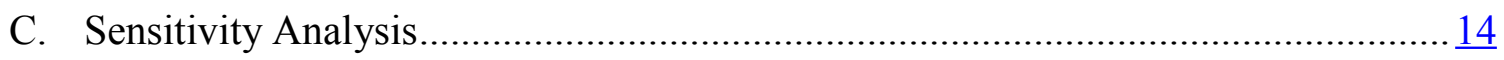

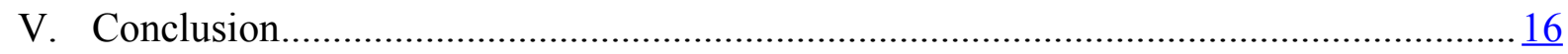

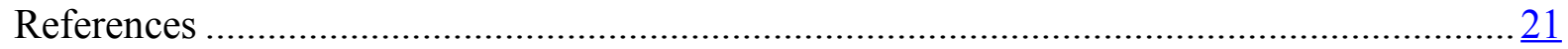

Figures

1. Philippines: Investment ................................................................................... $\underline{3}$

2. ASEAN: Public Investment and Public Capital Stock ................................................ $\underline{6}$

3. ASEAN: Quality of Public Infrastructure ............................................................. 7

4. Philippines: Governance Quality_Cross-Country Percentile Ranking .......................... $\underline{6}$

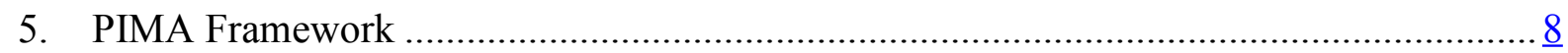

6. Cross-Country Comparison of Public Investment Efficiency ....................................... $\underline{9}$

7. Main Stimulation Results .............................................................................. 13

8. Sovereign Risk Premium for Different Assumption .................................................. 14

9. Alternative Borrowing Cost Results ................................................................. 15

10. Alternative Revenue Mobilization Results ............................................................. 17

Annex

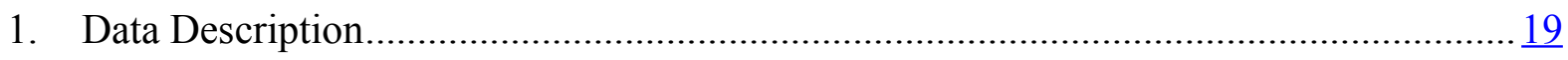




\section{INTRODUCTION}

Upgrading public infrastrcture is a major structural challenge in the Philippines. At 21.8 percent of GDP in 2014, the investment rate in the Philippines is well below regional peers (Figure 1). The main impediments to private investment are inadequate infrastructure, a weak investment climate, and restrictions on foreign direct investment. The low revenue base and fiscal consolidation have prevented sufficient resource allocation for public investment in the past, while weak implementation capacity has led to budget under-execution more recently, especially in 2013-14. Raising investment, particularly in infrastructure, would allow the country to reap the dividends of its young and growing population.

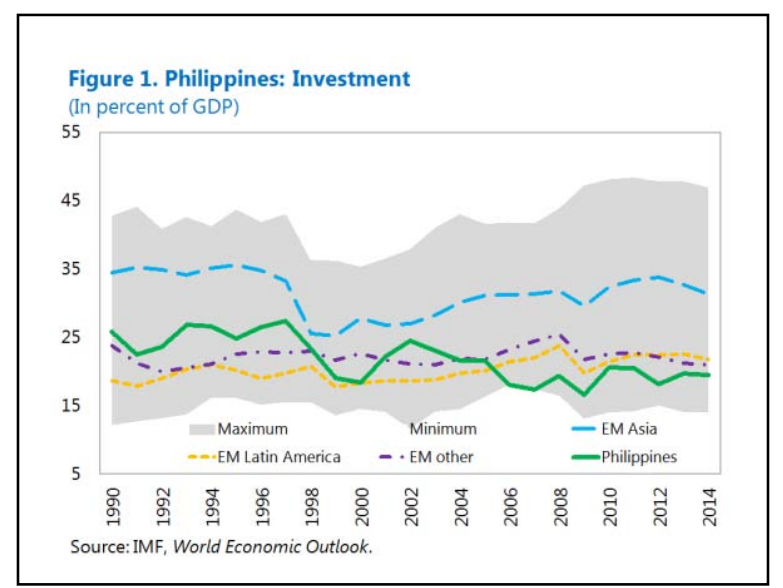

To address this issue, the government plans to increase infrastructure spending from 3 percent of GDP in 2014 to 5 percent by 2016, while also facilitating Public Private Partnership (PPP) projects. Immediate priorities include implementation of the transport system in Manila (Manila Dream Plan) and improvements in airports, road connectivity, and seaports across the country. Although there is a consensus that public infrastructure needs to be improved, the macroeconomic effects of doing so may differ depending on how this is done. First, there is a choice between deficit-financing and tax-financing to finance an increase in government spending. Moreover, the effect of the spending increase could be different depending on the public investment efficiency. In any case, it is important that the spending increase be done in a way that does not damage macroeconomic stability.

This paper explores the macroeconomic implications of improving public infrastructure by an increase in public investment expenditure. ${ }^{2}$ First, it benchmarks the Philippines relative to its neighbors in terms of the size of public investment and public capital stock; the quality of public infrastructure; and public investment efficiency. It confirms that the level of public capital stock and the quality of public infrastructure are low in the Philippines, and that there is room for improvement in public investment efficiency. Subsequently, the paper simulates alternative ways to enhance public infrastructure and their macroeconomic effects using the IMF's Global Integrated Monetary and Fiscal (GIMF) model.

Model simulations suggest that improving public infrastructure would result in a sustained output increase. Two types of scenarios are considered: (i) a permanent increase in public

\footnotetext{
${ }^{2}$ PPP will also play an important role in improving public infrastructure in the Philippines, as it has embarked on an ambitious PPP program. Moreover, appropriate types of financing could be different depending on the types of projects. These considerations are outside the scope of this paper, however.
} 
investment by 2 percent of GDP, financed by borrowing, (ii) the same increase in public investment, financed by higher taxes. Two sub-scenarios are included within each scenario; ones with and without improvements in public investment efficiency. All scenarios exhibit sustained gains in output because improving public infrastructure leads to gains in productivity, which crowds in private investment. Specifically, real GDP is higher than the steady state by 4.5-6 percent after 15 years even without an improvement in public investment efficiency. The improvement in public investment efficiency generate substantial additional benefits. Assuming half of the inefficiency is eliminated in five years, the increase in real GDP after 15 years is 9-11 percent.

Alternative financing scenarios generate different dynamics in public debt, consumption, and investment. The deficit-financing scenario results in a substantial increase in the public debt-toGDP ratio, while the tax-financing scenario results in its slight decrease. The incraese in the public debt increases the borrowing cost and constrains investment over time in the deficitfinancing scenario. In contrast, consumption is initially subdued in the tax-financing scenario because the increase in the consumption tax lowers households' disposal income. While the output gains are initially higher in the deficit-financing scenarios, these gains become higher in the tax-financed scenarios over time, with the increase in the government's borrowing cost in the deficit-financed scenarios playing a key role.

Public infrastructure improvement influences the external current account and inflation. It leads to a worsening current account, thereby facilitating external rebalancing. It also generates additional domestic demand initially and thus inflationary pressures. Over time, the increase in supply capacity alleviates the inflationary pressures.

Sensitivity analyses exhibit expected results. In the deficit-financing scenario, the size of the increase in output, private investment and consumption, inflation, and the decrease in current account is negatively associated with the size of the premium in the borrowing cost. In the tax-financing case, the equal distribution of revenue mobilization to corporate income tax (CIT), personal income tax (PIT), and consumption tax results in a smaller negative effect on consumption initially, larger negative effect on investment, and lower output, relative to the baseline scneario of exclusively consumption tax financing. It should be noted, however, that rationalization of tax incentives have the potential to mobilize revenue while also mitigating negative effects on growth.

With a low capital stock and a fast growing young population, addressing the large infrastructure gap is needed to raise potential growth and reduce poverty and external imbalances. This paper shows that increasing public investment spending can generate sustained output growth, and improving public investment efficiency can bring about substantial additional benefits. It also shows that deficit-financing and tax-financing can have different dynamics in some macroeconomic variables. Given the need to ensure debt sustainability amid the large spending needs in other priority spending areas for inclusive growth, continued efforts mobilize revenue will be critical, including by enacting measures to offset any revenue eroding 
policy changes and preferably through a comprehensive tax reform that focuses on broadening the tax base.

\section{LITERATURE REVIEW}

This study is closest to the studies that investigate the quantitative effects of public investment increase on economic growth using dynamic general equilibrium models (DGE). While DGE has been applied to a wide variety of countries to examine the effect of public investment scaleup (see Elekdag and Muir (2014) for application to Germany, for example), few of them incorporate public investment efficiency outside of application to low income countries. ${ }^{3}$ IMF (2014) takes a first step in modeling the effect of public investment efficiency. This paper extends it by allowing for dynamic changes in the public investment efficiency and interacting them with the public investment scale-up.

There is an extensive empirical literature on the effect of public investment and public infrastructure on economic growth, but results are not conclusive. There are several issues, including data availability on infrastructure, measurement of infrastructure spending and its efficiency, and potential reverse causation in which higher economic growth generates an increase in public capital spending. Straub (2008), Romp and de Haan (2005), and Pereira and Andraz (2013) provide comprehensive reviews. IMF (2014) and IMF (2015a) are among the attempts to control for public investment efficiency. They estimate stronger growth effects of public investment for the high public investment efficiency regime, consistent with the specification in our model.

Weak public infrastructure and low public investment in the Philippines have been welldocumented in the literature. Historical accounts include Montes (1986), Dohner and Intal (1989), Rodlauer and others (2000), Bocchi (2008), and Warner (2014). The literature consistently document low investment rates for the Philippines and consider this a major challenge. It also documented governance and public investment management problems.

\section{The State of Public Infrastructure in the Philippines}

\section{A. Level of Public Capital}

\section{Persistently low public investment in the Philippines has resulted in a low public capital stock relative to its neighbors. IMF (2015a) measures public investment and the stock of public capital for a large sample of countries, finding that the Philippines' public investment had consistently been the lowest among ASEAN countries in the recent past, averaging 2.5 percent of GDP in 2000-14 (Figure 2, left panel). As a result, the public capital stock is also one of the}

\footnotetext{
${ }^{3}$ There is a series of papers such as Buffie and others (2012), Melina and others (2014), Gupta and others (2015), and Balma and Ncube (2015), that studies financing for development and scaling-up public infrastructure using a model specified to capture economic structure of low-income developing countries.
} 
lowest among ASEAN countries, at around 35 percent of GDP in 2013 compared to the ASEAN average of 72 percent of GDP (Figure 2, right panel).

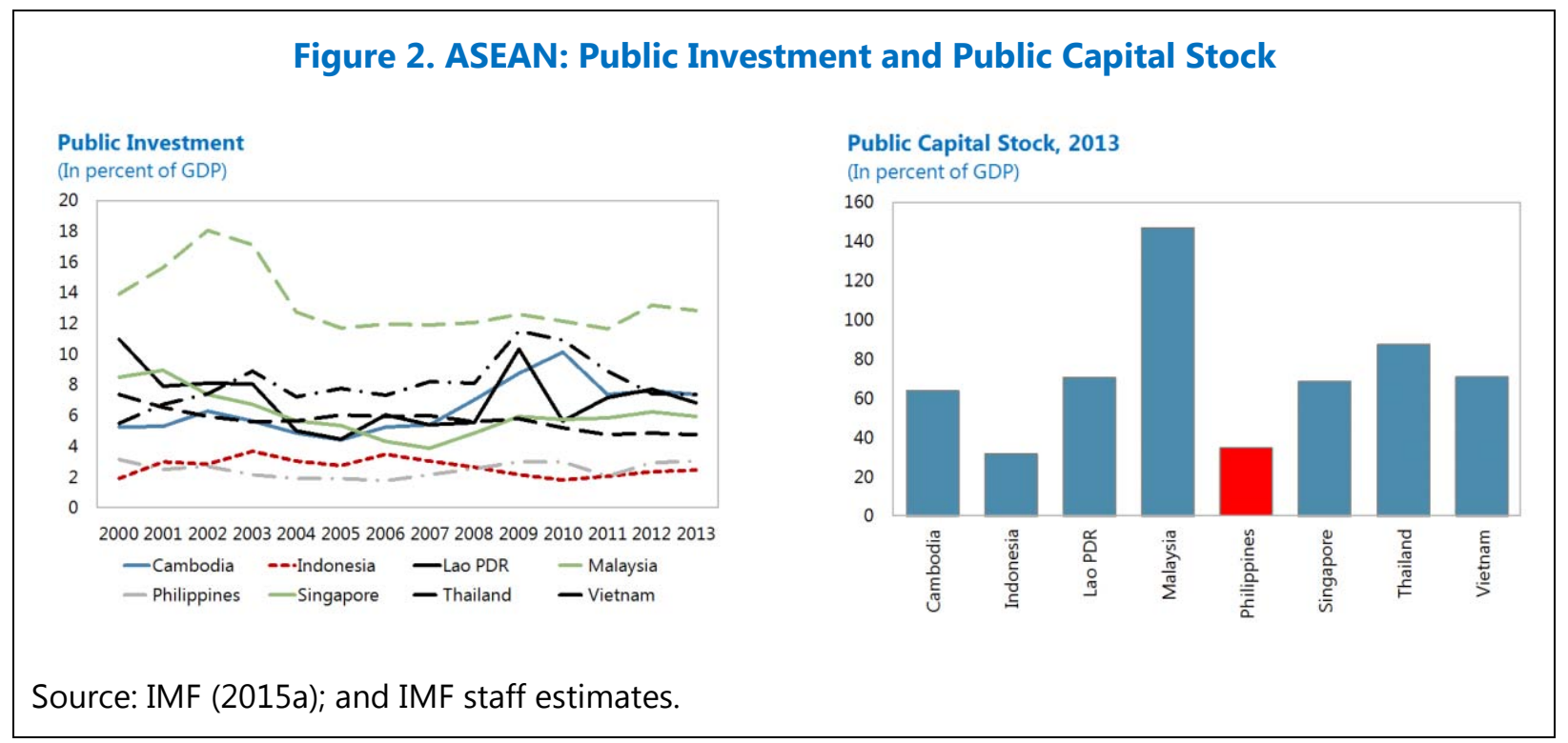

\section{B. Quality of Infrastructure}

Survey-based indicators also paint an unfavorable picture on the current state of public infrastructure in the Philippines. The World Economic Forum's global competitiveness report surveys business leaders' impressions on a wide-range of topics in the business environment on a 1-7 point scale. Regarding key infrastructure services, it places the Philippines among lowest in the ASEAN and substantially lower than the ASEAN average in overall infrastructure and all of its subcomponents (Figure 3).

\section{Public Investment Efficiency}

The Philippines has made steady progress in governance and fiscal transparency. Its relative ranking in the World Bank's World Governance Indicators has improved every year since 2010 (Figure 4). This reflects the high priority that the current administration has given to governance reform. Regarding fiscal transparency, IMF (2015b) assessed the Philippines' Public Financial Management (PFM) practices against the draft Fiscal Transparency Code covering the three pillars

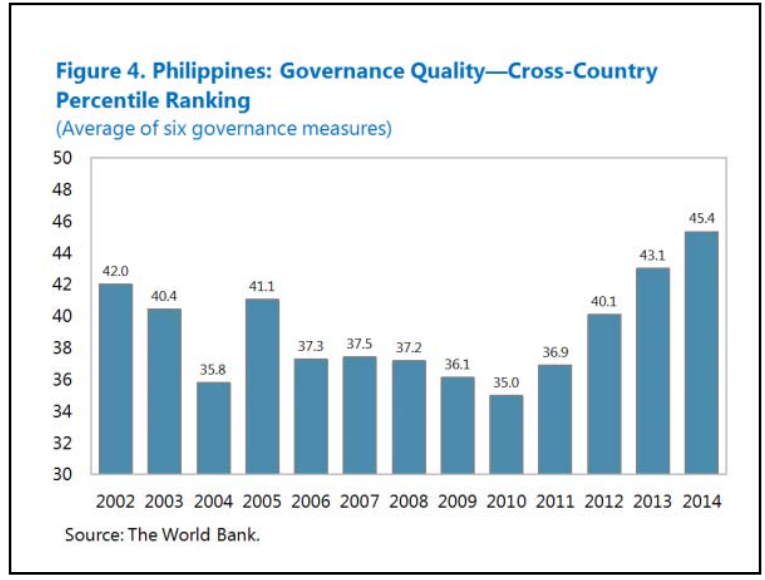


Figure 3. ASEAN: Quality of Public Infrastructure

(Scale 1-7)
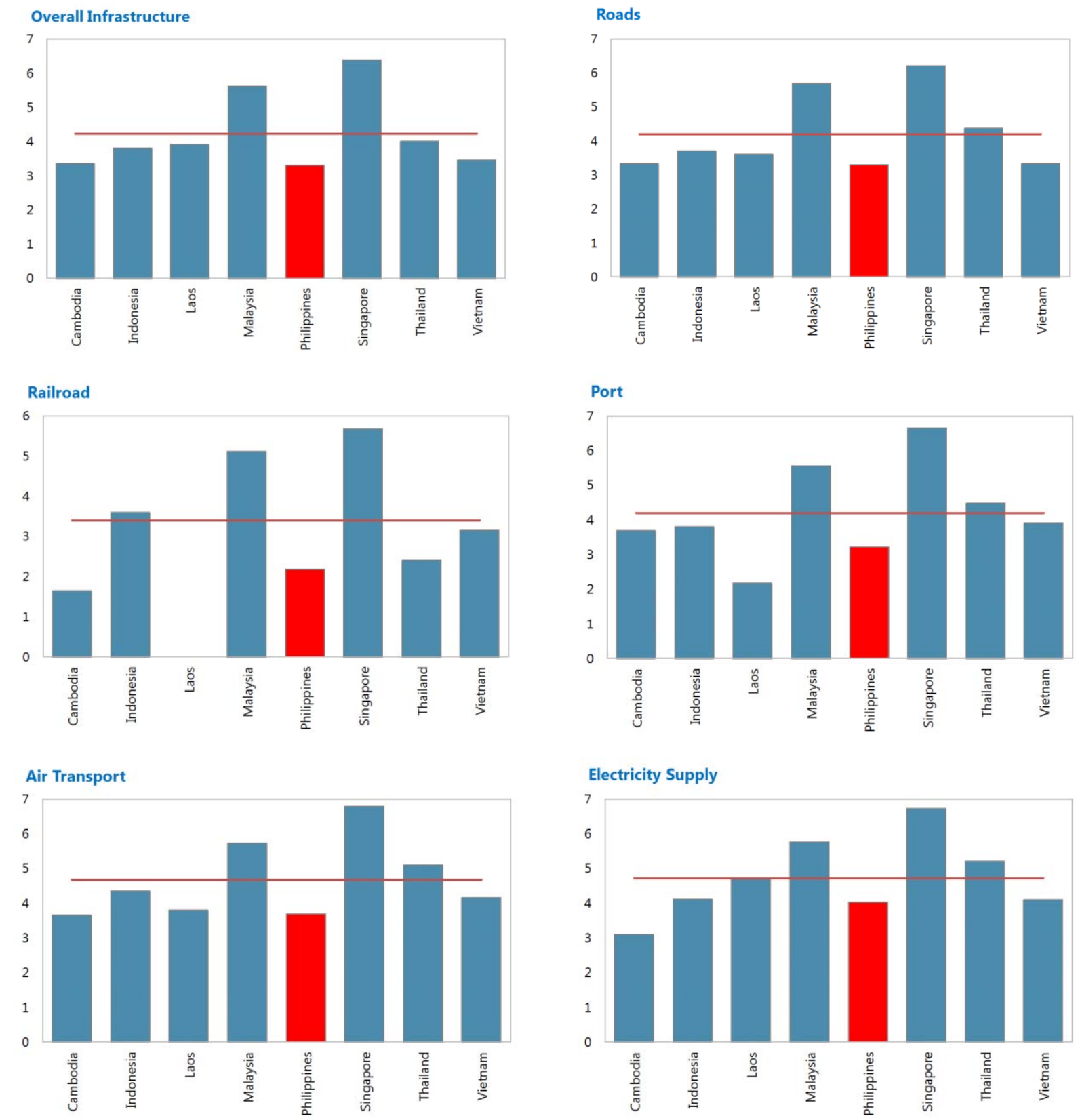

Source: World Economic Forum. 
of fiscal reporting, fiscal forecasting, and fiscal analysis and management. It acknowledged the authorities' reform efforts and reached broadly favorable conclusions. These developments indicate that there is a smaller risk of inefficient public investment due to governance issues.

However, there is still much room to strengthen institutions to improve public investment efficiency. The new Public Investment Management Assessment (PIMA) Framework developed by the IMF assesses the strength of public investment management (PIM) institutions. The PIMA evaluates 15 institutions that shape decision-making at the three key stages of the public investment cycle (Figure 5): planning sustainable investment across the public sector; allocating investment to the right sectors and projects; and implementing projects on time

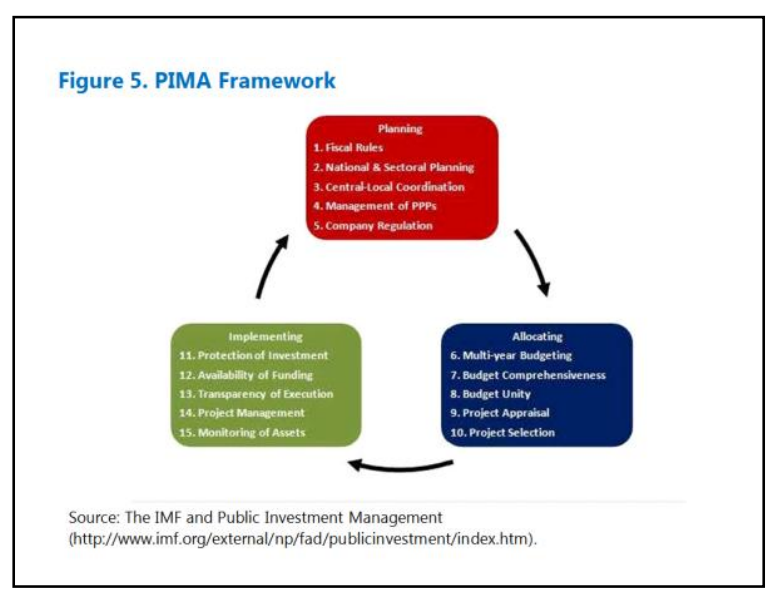
and on budget. Initial PIMA desk studies showed that the Philippines' PIM institutions are generally stronger in planning and implementing phases but weaker in allocating phase compared to the average of emerging and developing Asian countries. ${ }^{4}$ Among the 15 institutions, the Philippines are relatively strong on national planning, management of public private partnership, and project selection. However, it has relatively weak institutions in fiscal rules, multiyear budgeting, and budget unity.

Consistent with this, a 2014 IMF technical assistance on the medium term budget framework reports that a medium-term planning system has been established in Philippines Development Plan (PDP) and the Public Investment Program (PIP), but the link between planning and budgeting should be strengthened. Priorities include: undertaking a critical review of the stock of development projects to eliminate duplications, unnecessary projects, and those that are no longer priorities; anchoring planning within an overall medium term resource framework and improving high level coordination; strengthening the gate-keeping role played by budget agencies to choose projects appropriately for inclusion in the budget from the long list of candidates; and improving departments' appraisal, prioritization, and selection of projects, including multiyear budget preparation at spending agencies. The new PFM bill, if passed, would be helpful in addressing these areas and improving the PFM in general by institutionalizing the reform efforts and establishing and clarifying fundamental elements of PFM framework. Moreover, the authorities continue to make progress on project implementation. Measures taken in 2015 include making available or releasing the funds at the start of the year, administrative measures to clear procurement bottlenecks, and strengthening of

\footnotetext{
${ }^{4}$ The PIMA desk study included 7 countries namely Cambodia, China, India, Indonesia, Philippines, Nepal and Sri Lanka. In the coming years, the IMF expects to expand its database of PIMA results as countries request support for the reform of their PIM systems.
} 
procurement units at government agencies. These measures appear to have led to an improvement in government disbursements for infrastructure spending.

An outcome-based estimation of public investment efficiency also suggests substantial room for improvement. IMF (2015a) develops the Public Investment Efficiency indicator (PIE-X) (Figure 6). First, the public capital stock (input) and indicators of access to, and the quality of, infrastructure assets (output) are documented for over 100 countries. Then the public investment efficiency frontier is estimated as the highest levels of the output that can be achieved for fiven levels of input. Finally, the efficiency score is derived for each country as a distance from the frontier. It is higher if a given level of public capital stock is associated with a higher access and quality of infrastructure assets. The score is defined separately for advanced, emerging market, and low income economies, as there is a large divergence in income per capita, and the relationship between input and output is likely to be non-linear as income per capita increases. The estimation results show that the efficiency gap is 27 percent for EMEs on

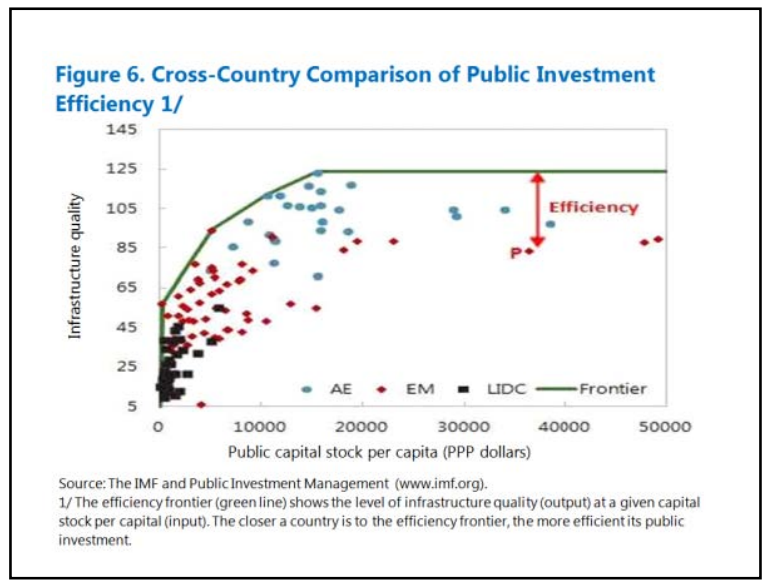
average, but substantially larger for the Philippines. ${ }^{5}$

\section{GIMF Simulations}

\section{A. Model and Calibration}

This section simulates the macroeconomic effects of public infrastructure improvement using the GIMF model. The GIMF is a multi-region general equilibrium macroeconomic model developed by the IMF's Research Department. It has optimizing firms and households, frictions in the form of sticky prices and wages and real adjustment costs, a financial accelerator mechanism, monetary policy that follows inflation forecast targeting, and fiscal policy that ensures debt sustainability. The model allows for discretionary fiscal policy in the short-run, and includes a detailed description of fiscal policy that allows for the choice of seven different fiscal policy instruments for fiscal adjustment, encompassing both revenue and expenditure measures. Moreover, the finite lifetime of households, some of whom are liquidity constrained, implies that the model generates strong macroeconomic responses to fiscal shocks. Kumhof and others (2010) and Anderson and others (2013) elaborate further on the theoretical structure and main simulation properties of the GIMF model.

\footnotetext{
${ }^{5}$ Country-specific estimates on the size of inefficiency are not public information.
} 
Government investment spending augments the stock of publicly provided infrastructure capital per capita $K_{t}^{G 1}$, the evolution of which is, after rescaling by growth in technology $(\mathrm{g})$ and population (n), given by: ${ }^{6}$

$$
K_{t+1}^{G 1}(1+g)(1+n)=\left(1-\delta_{G 1}\right) K_{t}^{G 1}+G_{t}^{i n v}
$$

$K_{t}^{G 1}$ contributes to the production of the final private-public composite good $Z_{t}^{D}$ by the following specification:

$$
Z_{t}^{D}=Y_{t}^{A}\left(K_{t}^{G 1}\right)^{\alpha_{G 1}} S
$$

where $Y_{t}^{A}$ is the private final good and $\mathrm{S}$ is a technology scaling factor used to normalize steady state technology to one. In turn, $Y_{t}^{A}$ is a composite of the tradable and non-tradable goods, which are produced by standard CES functions with capital and labor as input. Thus a higher $K_{t}^{G 1}$ increases marginal productivity of capital and labor.

The version of the model applied to this paper has three regions: the Philippines, rest of Asia, and the rest of the world. However, in this paper our focus is exclusively on the Philippines. Parameters for the Philippines are calibrated to the current state of the Philippines economy. In particular, long-run overall fiscal deficit to GDP ratio $\left(-g s s_{t}^{\text {rat }}\right)$ to about 2 percent of GDP, following the current administration's commitment. This implies long-run debt-to-GDP ratio ( $b s s_{t}^{r a t}$ ) of 45 percent.

This paper departs from the standard specification in two areas. First, it is assumed that not all public investment spending contributes to the formation of public capital. Specifically, part of the budgeted public investment is reclassified as public consumption, which is unproductive by construction, in the model. ${ }^{7}$ The size of the reclassification is dependent of the degree of inefficiency, which is set as 40 percent in the baseline. ${ }^{8}$ Reflecting this assumption, steady state government investment is assumed to be 2 percent of GDP although officially it has been 3.3 percent of GDP on average since 2011 at the general government level.

Second, it is assumed that there is a premium in the government's borrowing cost that is increasing in the debt to GDP ratio. Following Schule (2010), it is specified as:

$$
\log \left(1+\text { premium }_{t}\right)=\beta_{1}+\beta_{2} /(B \lim i t-\bar{B} / \overline{G D P})^{\beta_{3}}+\epsilon_{t}
$$

\footnotetext{
${ }^{6} \mathrm{~N}$ and $\mathrm{g}$ are used in the model to allow for trend growth in technology and population that is region-specific while ensuring stationarity of the model.

${ }^{7}$ This specification follows a similar exercise in IMF (2014).

${ }^{8}$ This is broadly in line with the Philippines' PIE-X and PIMI scores relative to best performers.
} 
See annex for detailed properties of this specification. It is assumed that the premium increase by 3 basis points per increase in the debt-to-GDP ratio in the baseline, but we will also perform sensitivity analyses given the uncertainty on this calibration. The changes in the borrowing cost by the government are translated to the borrowing cost of the private sector in the GIMF model.

Two scenarios are considered: (i) a permanent increase in public investment by 2 percent of GDP, financed by borrowing; and (ii) the same increase in public investment, financed by higher consumption taxes. (i) implies a 2 percent of GDP increase in overall fiscal deficit. ${ }^{9}$ In (ii), consumption tax increases are chosen over labor and capital taxes in the baseline, in line with the Fund's recommendations..$^{10}$ Expenditure reallocation is not considered as a tool to finance public investment given the small size of total government expenditure in the Philippines and the existence of other spending priorities that makes it difficult to reallocate expenditure at a large scale.

Two sub-scenarios of public investment efficiency are included within each scenario. While the public investment inefficiency remains 40 percent in the status-quo case, half of the inefficiency is eliminated gradually over five years in the efficiency-improvement case.

\section{B. Baseline Results}

Both the deficit-financed and tax-financed public investment increases lead to sustained gains in real GDP (Figure 7). Public investment increases have sustained output effects beyond the direct demand effect of the spending increase because of the productivity-enhancing impact of public infrastructure. As public capital is an input to the aggregate production function of the economy, the improved public infrastructure raises the overall productivity, akin to an increase in total factor productivity from the perspective of the private sector. The resulting increase in marginal productivity of capital and labor crowd in the private investment and increase demand for labor, which induce a higher consumption due to higher household income. Even without an improvement in public investment efficiency, the increase in public investment results in a 4.5-6 percent cumulative increase in real GDP relative to the steady state after 15 years.

While the output gains are initially higher in the deficit-financed scenarios, these gains become larger in the tax-financed scenarios over time, with the increase in the government's borrowing cost in the deficit-financed scenarios playing a key role. The tax-financed scenario results in smaller output gains in the in the short-to-medium term because the tax increase reduces consumption, partially offsetting the demand increase from higher public investment. Over time,

\footnotetext{
${ }^{9}$ In order to ensure that all scenarios go back to the same level of debt-to-GDP ratio in the long-run, the deficitfinanced public investment scale up is limited to the first 25 years in (i). Our comparison focuses on the periods in which the public investment scale up is financed by the deficit in (i).

${ }^{10}$ IMF (2015c) states, "The authorities are urged to ensure net revenue enhancement in their tax reform package by rationalizing tax incentives, streamlining VAT exemptions, and raising fuel excises, to offset the losses from the proposed reductions in corporate and personal income taxes."
} 
however, the continuous increase in the debt-to-GDP ratio in the deficit-financed scenario increases domestic interest rates, with negative effects on private investment and consumption, and leading to decelerating output growth.

The increasing influence of the government's borrowing cost over time can be seen by comparing the paths of long-term real interest rates, the interest rate most relevant for investment decisions of the private sector. In the GIMF model, an increase in the government's borrowing cost due to an increase in the risk premium leads to a parallel increase in all domestic interest rates. Additionally, domestic interest rates are also affected by monetary policy. The long-term real interest rates reflect both of these factors, and increase on impact for both deficitfinanced and tax-financed scenarios. However, the increase is larger for the former partly due to the stronger demand effect but also in anticipation of the future increase in the risk premium. The paths further diverge from each other over time, driven by the increasing risk premium in the deficit-financed scenario.

Improving public investment efficiency generates a significant additional impact. Raising public investment efficiency to about 80 percent efficiency increases output by 5 percent after 15 years compared with the unchanged efficiency scenarios, for both tax-financed and deficit-financed scenarios. The difference in public infrastructure contribution is sizable because of the large efficiency gap. For example, given the 40 percent assumed inefficiency, the 5 percent of GDP public investment results in only about 3 percent of GDP contribution to public infrastructure. When public investment efficiency is improved to the 20 percent inefficiency, the same 5 percent of GDP public investment results in over 4 percent of GDP contribution to public infrastructure and a cumulative increase in GDP of 9-11 percent after 15 years. This improvement in efficiency generates balanced effects, increasing consumption and investment and decreasing the debt-to-GDP ratio relative to the scenarios without improvements in public investment efficiency.

Additional demand from higher public infrastructure gives rise to inflationary pressures and a positive output gap, inducing an increase in the policy interest rate. Different degrees of inflation can be explained by the different sizes of private investment crowding in and the resulting consumption increase. Over time, the increase in supply capacity alleviates the inflationary pressures and the policy rate increase is gradually reversed in all scenarios.

The current account exhibits a sustained deterioration, mostly because of higher imports. Exports also decline initially due to the initial real appreciation associated with the policy interest rate increase. Subsequently, exports increase as investment stimulates production and the initial real appreciation is reversed in line with the reversal of initial monetary tightening, which partially offsets the reduction of the current account. The size of the current account deficit increase is roughly proportional to the output increase and reaches $0.7-1.5$ percent of GDP after two years. 
Figure 7. Main Stimulation Results
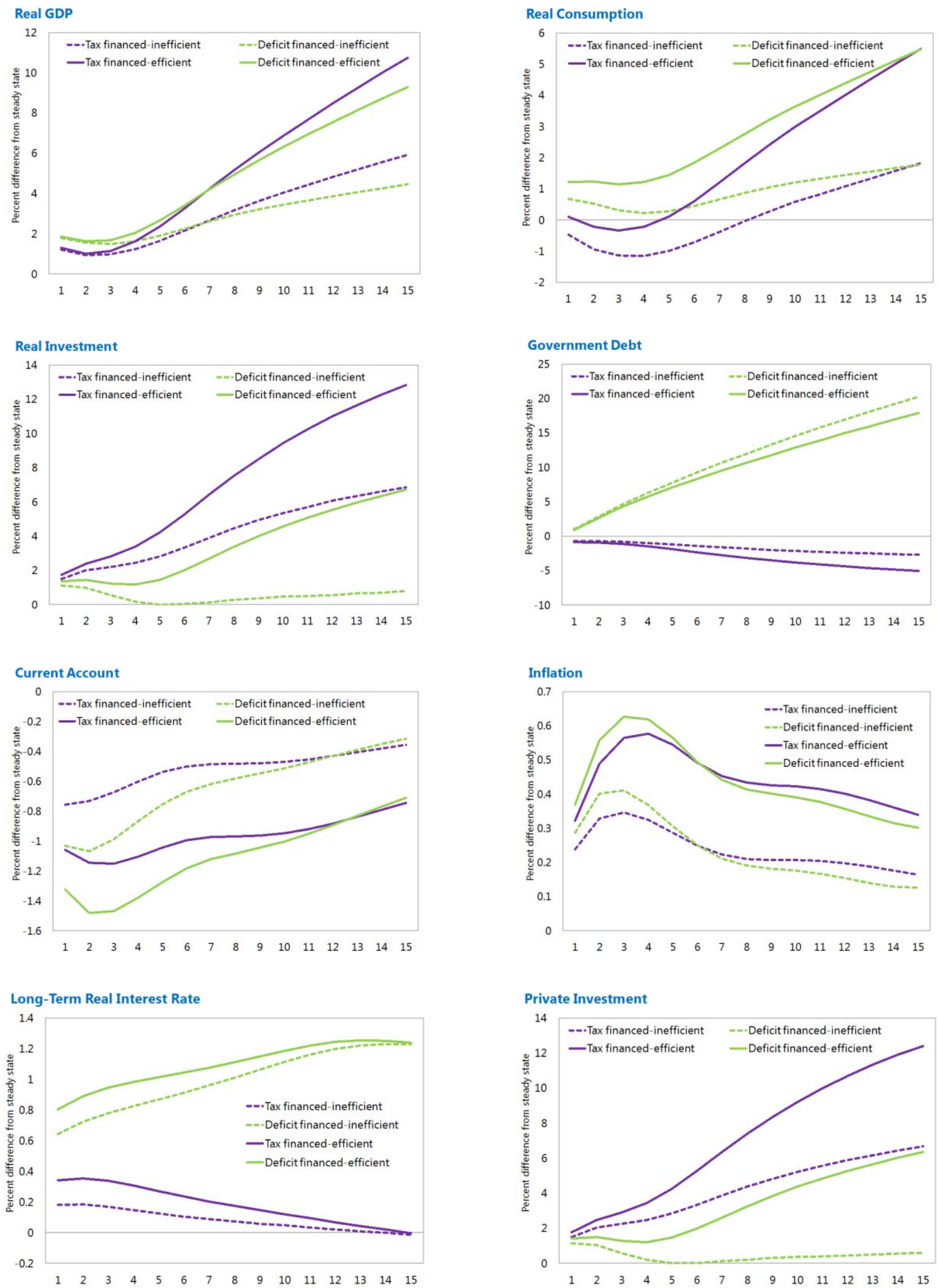


\section{Sensitivity Analysis}

This subsection considers two types of sensitivity analysis: changes in the assumption on the borrowing cost premium in the deficit-financed scenarios; and changes in the tax mix in the taxfinanced scenarios. ${ }^{11}$

\section{Alternative Borrowing Cost Premia}

Given the key role of the borrowing interest rates on the output dynamics, two additional calibrations on the borrowing cost premium are examined. A higher premium is likely to favor tax-financed scenarios more, while the opposite holds for a lower borrowing cost premium. At the same time, the relationship between public debt and the borrowing cost is uncertain, affected by various factors, including both global and local ones. ${ }^{12}$ A higher premium calibration sets the premium at 5 basis points per unit increase in the debt-to-GDP ratio. This draws on Peiris (2015), estimates determinants of 10-year government bond yields in the Philippines while controlling for a comprehensive list of variables, and finds the marginal effect of a unit increase in the debt-to-GDP ratio to be 5-6 basis points. Our baseline has adopted a lower estimate of the borrowing cost on the basis of recent improvements in the Philippines' fiscal management as reflected in credit rating upgrades in recent years, interpreting it as structural changes. It is also possible to assume that the transformation has led to even lower borrowing cost. This is the lower premium calibration, which assumes 1 basis point response per unit increase in the debt-to-GDP ratio. Figure 8 shows the

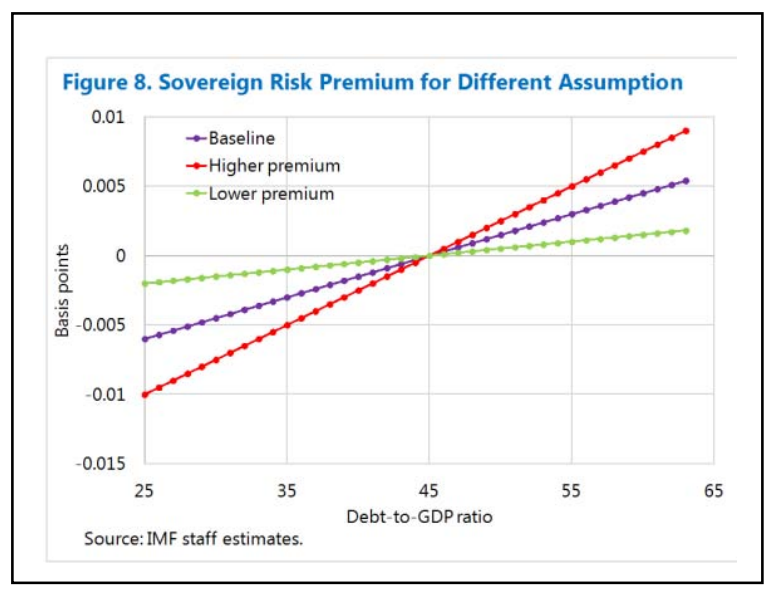
borrowing cost premia for the three scenarios.

Simulations show expected results (Figure 9). The higher the borrowing cost increase, the more subdued the effect of public investment scale up on output. Trajectories of all the other variables change accordingly. It should be noted that even under the lower premium calibration, real output increase slightly undershoots the tax-financed scenario after 15 years.

\footnotetext{
${ }^{11}$ Simulation results are based on no improvement in public investment efficiency. Improvements in public investment efficiency would result in parallel increase in output, investment, consumption, etc.

${ }^{12}$ Baldacci and Kumar (2010), and the review therein, estimate the response of the borrowing cost to range from 3-7 basis points per unit increase in the debt-to-GDP ratio.
} 
Figure 9. Alternative Borrowing Cost Results
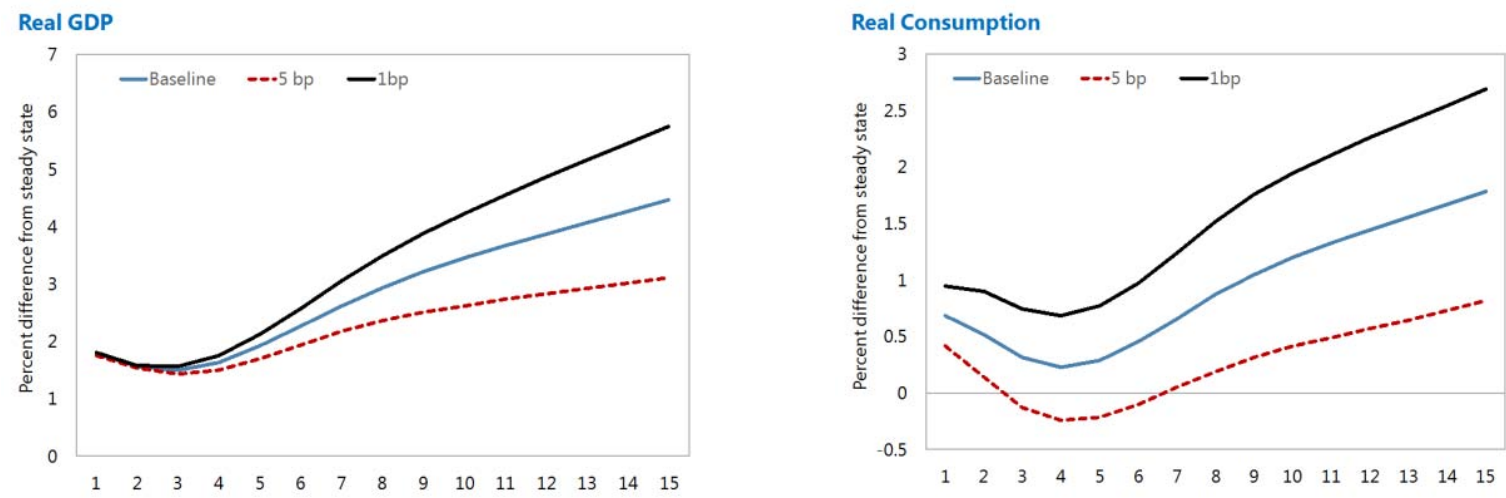

Real Investment

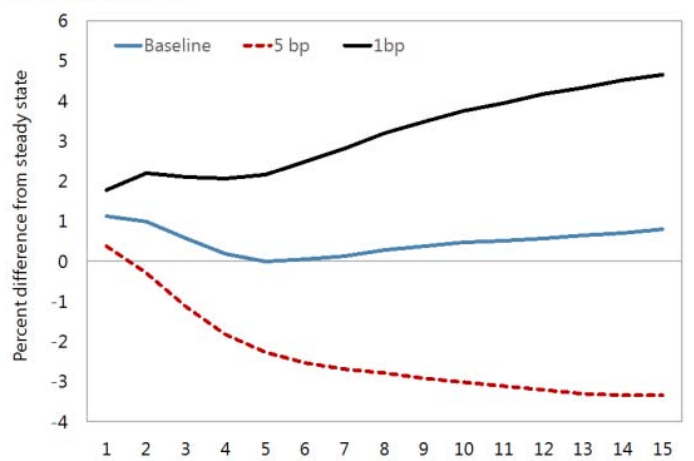

Government Debt

(In percent of GDP difference)

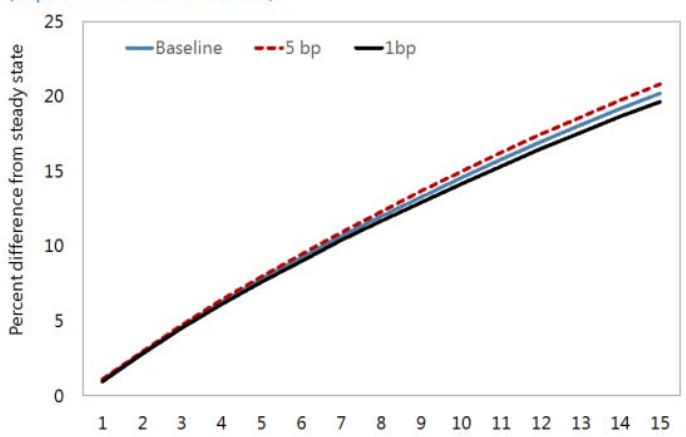

Current Account
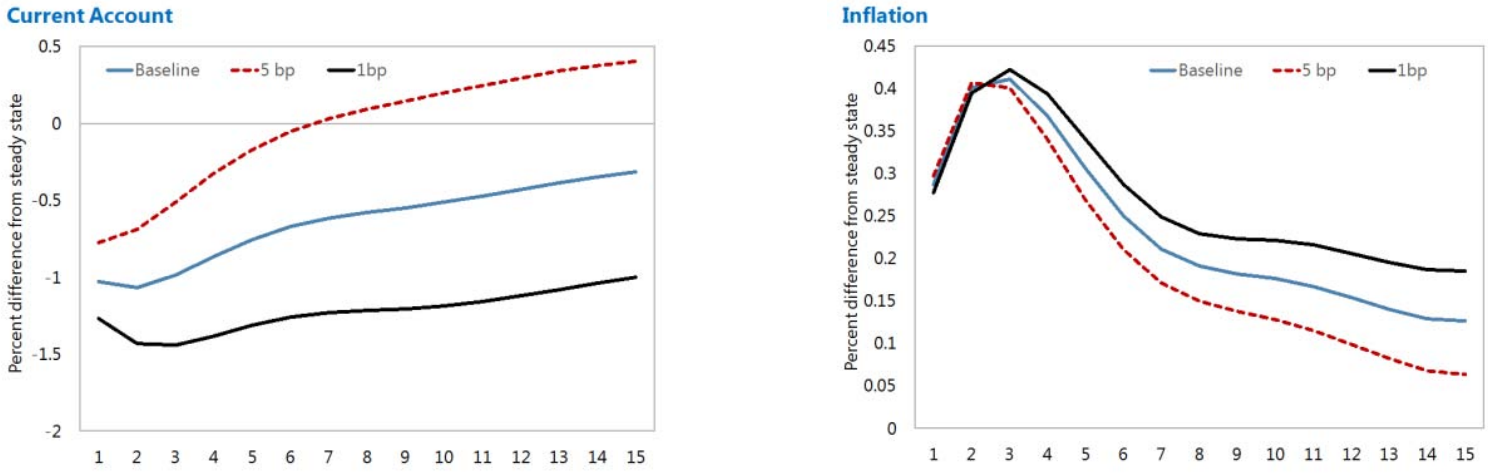

Long-Term Interest Rates
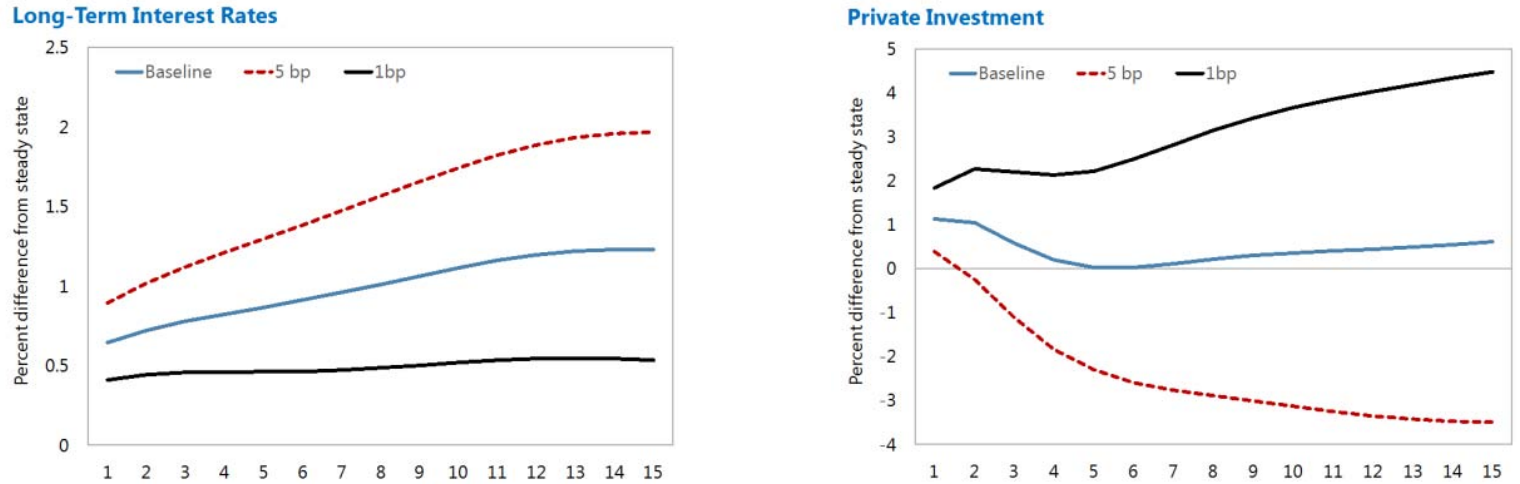


\section{Alternative Tax Incidence}

Revenue mobilization to finance public investment may require the use of multiple sources. Reliance solely on the consumption tax, assumed in the baseline scenario, implies an increase in the tax rate of around 3 percent. This may not be politically feasible. In order to capture this possibility, we assume that the revenue mobilization is equally distributed to CIT, PIT, and consumption tax in the alternative scenario.

Results show that there is less negative effect on consumption initially and more negative effect on investment (Figure 10). Output growth is lower in this alternative scenario than the baseline. The superiority of indirect taxes on growth is a general feature of the GIMF model (Anderson and others (2013)), and consistent with Lucas (1990) and Chari and others (1994), which demonstrate the distortionary effect of capital and labor taxation on investment and labor supply. It has also been established empirically on average, as documented in Johansson and others (2008) and Acosta-Ormaechea and Yoo (2012).

Rationalization of tax incentives have the potential to mobilize revenue while mitigating negative effects on growth. It has been shown that tax incentives in the Philippines are not welltargeted (Botman and others (2008)). Their rationalization could raise revenue without raising statutory rates, thus mitigating the negative effects on private investment. Tax exemptions are outside of the model in this paper, however.

\section{ConClusion}

This paper studied the macroeconomic implications of public investment scale up in the Philippines. After benchmarking the Philippines relative to its neighbors in terms of level of public capital and quality of public infrastructure, and public investment efficiency, it uses model simulations to assess the macroeconomic implications of raising public investment and improving public investment efficiency. It found the following results.

Philippines' public infrastructure is below that in the neighboring countries. Persistently low public investment in the Philippines has resulted in a low public capital stock relative to its neighbors. Survey-based indicators also paint an unfavorable picture on the current state of public infrastructure in the Philippines.

Public investment efficiency has room for improvement. The Philippines has made steady progress in governance and fiscal transparency. However, there is still much room to strengthen institutions to improve public investment efficiency. Both institution-based assessment and an outcome-based estimation of public investment efficiency suggest substantial room for improvement. 


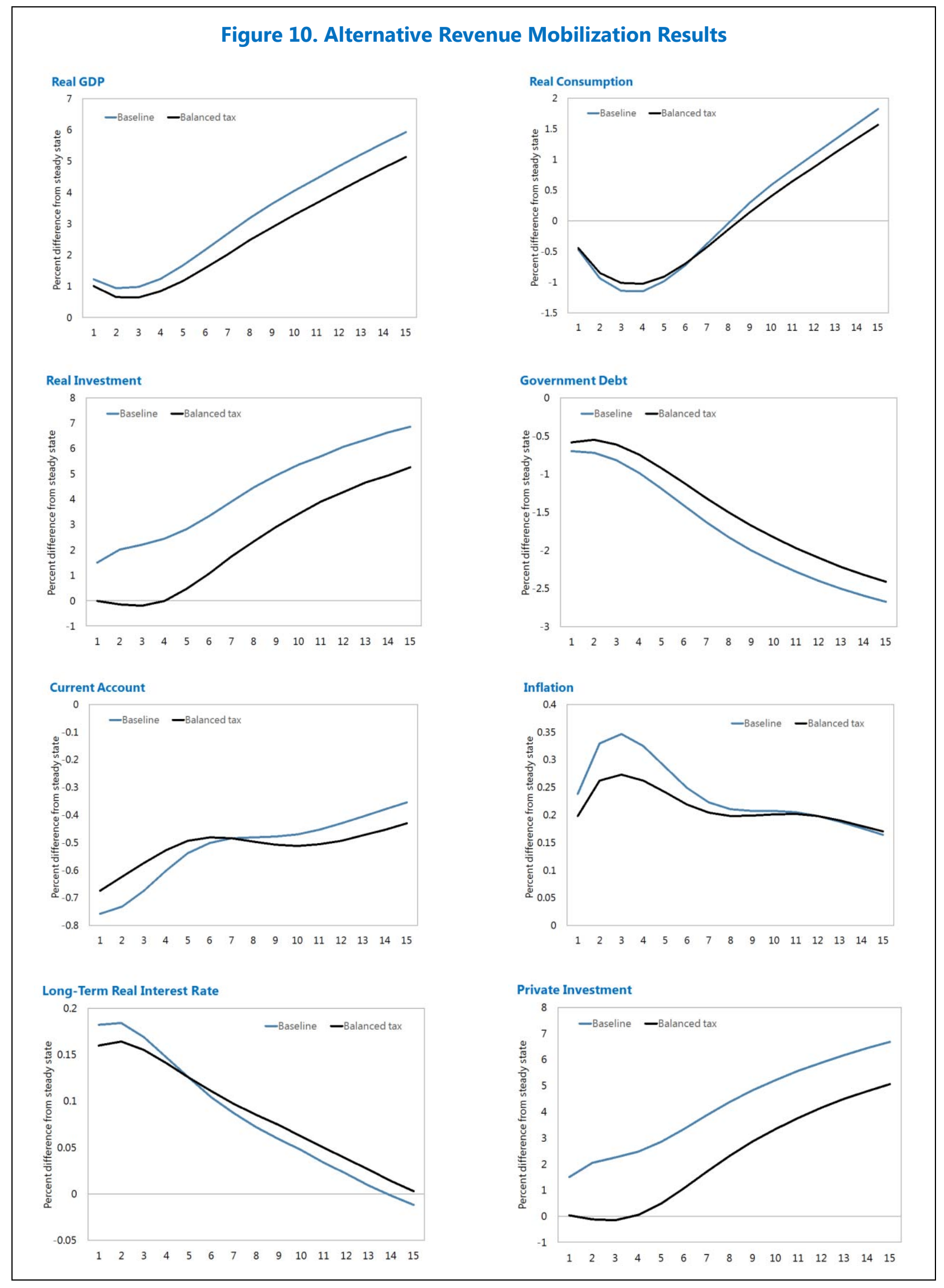


Public investment scale-up results in a sustained growth. Even without an improvement in public investment efficiency, the increase in public investment results in a 4.5-6 percent cumulative increase in real GDP relative to the steady state after 15 years. Improving public investment efficiency has substantial additional benefits. Eliminating half of the inefficiency would lead to real GDP higher by 5-6 percentage points.

With a low capital stock and a fast growing young population, addressing the large infrastructure gap is needed to raise potential growth and reduce poverty and external imbalances. This paper shows that increasing public investment spending can generate sustained output growth, and improving public investment efficiency can bring about substantial additional benefits. It also shows that deficit-financing and tax-financing can have different dynamics in some macroeconomic variables. Given the need to ensure debt sustainability amid the large spending needs in other priority spending areas for inclusive growth, continued efforts mobilize revenue will be critical, including by enacting measures to offset any revenue eroding policy changes and preferably through a comprehensive tax reform that focuses on broadening the tax base. 


\section{Annex 1. Data Description}

The sovereign risk premium formula is the following:

$$
\log \left(1+\text { premium }_{t}\right)=\beta_{1}+\frac{\beta_{2}}{\left(B \lim i t-B_{t} / G D P_{t}\right)^{\beta_{3}}}+\epsilon_{t}
$$

Where $\epsilon_{t}$ is an exogenous shock.

Set $\beta_{1}=-\frac{\beta_{2}}{(B \lim i t-\bar{B} / \overline{G D P})^{\beta_{3}}}$ so that $\log \left(1+\right.$ premium $\left._{t}\right)=0$ at steady state.

$\beta_{2}$ and $\beta_{3}$ are set so that the risk premium is increasing and convex in the debt-to-GDP ratio.

As shown below, this implies $\beta_{2} \beta_{3} \geq 0$ and $\beta_{3} \geq-1$.

$\beta_{3}$ controls the degree of non-linearity. A higher $\beta_{3}$ represents more non-linearity. As a special case, $\beta_{3}=-1$ reduces the risk premium formula to a linear form in the debt-to- GDP ratio.

Given $\beta_{3}, \beta_{2}$ is used to calibrate the slope of the formula to empirically plausible value at the steady state. Because the slope is:

$$
\left.\frac{\partial\left(\log \left(1+\operatorname{premium}_{t}\right)\right)}{\partial\left(B_{t} / G D P_{t}\right)}\right|_{B_{t} / G D P_{t}=\bar{B} / G D P}=\beta_{2} \beta_{3}\left(B \lim i t-\frac{\bar{B}}{G D P}\right)^{-\beta_{3}-1}
$$

Setting $\beta_{2} \beta_{3}\left(B \lim i t-\overline{\frac{B}{G D P}}\right)^{-\beta_{3}-1}=x$ implies $\beta_{2}=x \beta_{3}^{-1}\left(B \lim i t-\overline{\frac{B}{G D P}}\right)^{\beta_{3}+1}$ 


\section{Proposition}

Assuming that the debt-to-GDP ratio is always below the debt limit, the risk premium is increasing and convex in the debt-to-GDP ratio if and only if $\beta_{2} \beta_{3} \geq 0$ and $\beta_{3} \geq-1$.

Proof:

$\frac{\partial\left(\log \left(1+\text { premium }_{t}\right)\right)}{\partial\left(B_{t} / G D P_{t}\right)}=\beta_{2} \beta_{3}\left(B \lim i t-\frac{B_{t}}{G D P_{t}}\right)^{-\beta_{3}-1} \geq 0$ if and only if $\beta_{2} \beta_{3} \geq 0$

$\frac{\partial^{2}\left(\log \left(1+\operatorname{premium}_{t}\right)\right)}{\partial^{2}\left(B_{t} / G D P_{t}\right)}=-\beta_{2} \beta_{3}\left(-\beta_{3}-1\right)\left(B \lim i t-\frac{B_{t}}{G D P_{t}}\right)^{-\beta_{3}-2} \geq 0$ if and only if $-\beta_{3}-1 \leq 0$

- If $\frac{B_{t}}{G D P}$ increases from the steady state, risk premium increases faster. On the other hand,

if $\frac{B_{t}}{G D P}$ decreases from the steady state, risk premium decreases slower.

- $\quad$ Blimit should be set slightly higher than the historical maxium debt-to-GDP ratio. 


\section{References}

Acosta-Ormaechea, Santiago and Jiae Yoo 2012, "Tax Composition and Growth: A Broad Cross-Country Perspective”, IMF Working Paper No. 12/257 (Washington: International Monetary Fund).

Anderson, Derek, Benjamin Hunt, Mika Kortelainen, Michael Kumhof, Douglas Laxton, Dirk Muir, Susanna Mursula, and Stephen Snudden, 2013, "Getting to Know GIMF: The Simulation Properties of the Global Integrated Monetary and Fiscal Model”, IMF Working Paper No. 13/55 (Washington: International Monetary Fund).

Baldacci, Emanuele, and Manmohan S. Kumar, 2010, "Fiscal Deficits, Public Debt, and Sovereign Yields”, IMF Working Paper No. 10/184 (Washington: International Monetary Fund).

Balma, Lacina and Mthuli Ncube, 2015, "Macroeconomic Challenges of Structural Transformation: Public Investment, Growth and Debt Sustainability in Sierra Leone", IMF Working Paper No. 15/164 (Washington: International Monetary Fund).

Bocchi, Alessandro Magnoli, 2008, "Rising Growth, Declining Investment: The Puzzle of the Philippines", World Bank Policy Research Working Paper 4472

Botman, Dennis, Alexander Klemm, and Reza Baqir, 2008, "Investment Incentives and Effective Tax Rates in the Philippines: A Comparison with Neighboring Countries", IMF Working Paper No. 08/207 (Washington: International Monetary Fund).

Buffie, Edward F., Berg, A., Pattillo, C.A., Portillo, R., and L.F. Zanna, 2012, "Public Investment, Growth, and Debt Sustainability: Putting Together the Pieces," IMF Working Paper No. 12/144 (Washington: International Monetary Fund).

Chari, V.V., Lawrence J. Christiano, and Patrick J. Kehoe, 1994, "Optimal Fiscal Policy in a Business Cycle Model”, Journal of Political Economy 102 (4): 617-52

Dohner and Intal 1989, “The Marcos Legacy: Economic Policy and Foreign Debt in the Philippines", in Developing Country Debt and Economic Performance, Volume 3: Country Studies- Indonesia, Korea, Philippines, Turkey, National Bureau of Economic Research

Elekdag, Selim and Dirk Muir, 2014 "Das Public Kapital: How Much Would Higher Germany Public Investment Help Germany and the Euro Area?”, IMF Working Paper No. 14/227 (Washington: International Monetary Fund). 
Gupta, Pranav., Li, G.B., and Yu, J., 2015, "From Natural Resource Boom to Sustainable Economic Growth: Lessons for Mongolia” IMF Working Paper No. 15/90 (Washington: International Monetary Fund).

International Monetary Fund, 2014, World Economic Outlook, October 2014, World Economic and Financial Survey, Chapter 3 (Washington).

International Monetary Fund, 2015a, “Making Public Investment More Efficient,” IMF Policy Paper. Available via the Internet: http:/www.imf.org/external/np/pp/eng/2015/061115.pdf.

International Monetary Fund, 2015b, Philippines-Fiscal Transparency Evaluation, IMF Country Report No. 15/156 (Washington).

International Monetary Fund, 2015c, Philippines-2015 Article IV Consultation, IMF Country Report No. 15/246 (Washington).

Johansson, Asa, Christopher Heady, Jens Arnold, Ber Brys and Laura Vartia , 2008, "Tax and economic growth", mimeo.

Kumhof, Michael, Douglas Laxton, Dirk Muir, and Susanna Mursula, 2010, "The Global Integrated Monetary and Fiscal Model (GIMF)—Theoretical Structure,” IMF Working Paper No. 10/34 (Washington: International Monetary Fund).

Lucas, Robert E. 1990, "Supply-side economics: an analytical review”, Oxford Economic Papers, vo.42, 293-316

Melina, Giovanni, Yang, S., and L.F. Zanna., 2014, "Debt Sustainability, Public Investment, an Natural Resources in Developing Countries: the DIGNAR Model” IMF Working Paper No. 14/50 (Washington: International Monetary Fund).

Montes, Manuel, 1986, "Financing Development: The Political Economy of Fiscal Policy in the Philippines," Philippines Institute for Development Studies

Peiris, Jaynath Shanaka, 2015, “Global Financial Cycles, Volatility and the Philippines”, IMF Country Report No. 15/247, Chapter 1 (Washington: International Monetary Fund)

Pereira, Alfredo Marvão, Jorge M. Andraz, 2013, "On the economic effects of public infrastructure investment: A survey of the international evidence", mimeo. 
Rodlauer, Markus, Prakash Loungani, Vivek Arora, Charalambos Christofides, Enrique G. de la Piedra, Piyabha Kongsamut, Kristina Kostial, Victoria Summers, and Athanasios Vamvakidis, 2000, "Philippines: Toward Sustainable and Rapid Growth Recent Developments and the Agenda Ahead", Occasional Paper 187 (Washington: International Monetary Fund)

Romp, Ward, and Jakob de Haan, 2005, "Public capital and economic growth: a critical survey", EIB papers Vol. 10 No. 1

Straub, Stéphane, "Infrastructure and Growth in Developing Countries”, World Bank Research Working Paper 4460

Warner, Andrew, 2014, "Public Investment as an Engine of Growth", IMF Working Paper No. 14/148 (Washington: International Monetary Fund)

Schule, Werner, 2010, “The Potential Contribution of Fiscal Policy to Rebalancing and Growth in New Zealand", IMF Working Paper No.10/28 (Washington: International Monetary Fund) 